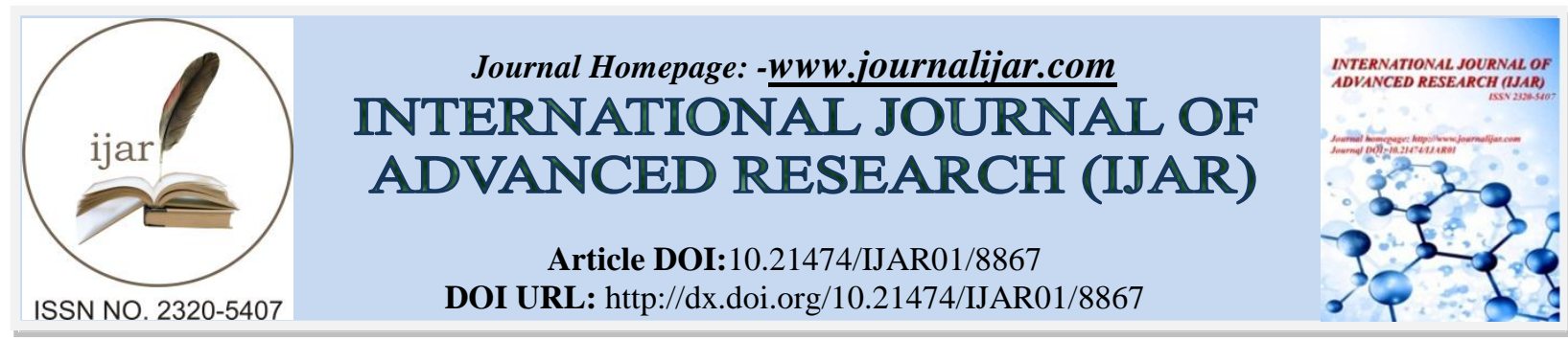

RESEARCH ARTICLE

\title{
STUDY AND EFFECT OF FUNGICIDES TO CONTROL THE FUNGAL CONTAMINATION OF IN- VITRO FLOWERING PLANT, ANTHURIUM ANDREANUM.
}

Subhashree Satapathy ${ }^{1}$ and Dr Gurudutta Pattnaik ${ }^{2}$.

Subhashree Satapathy, Bhubaneswar and 751019, India.

\section{Manuscript Info}

\section{Manuscript History}

Received: 10 February 2019

Final Accepted: 12 March 2019

Published: April 2019

Key words:-

Embryo culture;Penicilliumcrysogenum;

Fusarium; Aspergillusniger;

Alternariaspp; Penicilliumspp;

Aspergillusoryzae ; Cladosporium.

\begin{abstract}
For the large production of plants; tissue, organ, embryo culture, cell may act as an important technique for the in-vitro plant culture to produce the disease-free plants, crop improvement via gene transfer and through cryopreservation. This paper presents the fungal contamination of Anthuriumandreanum was caused by fungus like Penicilliumcrysogenum, Fusarium, Aspergillusniger, Alternariaspp, Penicilliumspp, Aspergillusoryzae, Cladosporium and then controlling the contamination by the effect of fungicides. All the experiments were completed in vitro at Biotechnology cum Tissue Culture Centre (BTCC) OUAT centre, Bhubaneswar. The fungal contamination and controlling procedures were kept in the incubator for at least 1 week at $27.5^{\circ} \mathrm{C}$.
\end{abstract}

Copy Right, IJAR, 2019,. All rights reserved.

\section{Introduction:-}

Tissue culture is a general term that includes a set of techniques used for culture of cells, tissues or organs in a suitable nutrient culture medium of known composition under aseptic condition in a micro environmental chamber maintained with optimized temperature, photoperiod and humidity. Tissue culture technique was based upon Totipotency that is the ability of a single cell to regenerate into a whole new individual when provided with suitable environmental conditions. The cells remained alive for up to one month, increased in size, accumulated starch but failed to divide. Though this was unsuccessful but the foundation of tissue culture technology was invented. The vital part for this procedure is to sustain a hygienic surrounding as possible. By the way a small bacterial cell or fungal spore which comes into contact with the grown media may rapidly reproduce and completely very soon overwhelm the tiny plant pieces which were tried to clone. The in-vitro plant techniques that includes cells, tissues, organs and embryo cultures must be a vital technique for mass production of plants to produce disease free plants through cryopreservation and the development of crops by transferring genes [1,2,3,4 et al.].

The equipments used in in-vitro were of high cost such as water, chemicals (like regulators or plant growth hormones, sterilizing agents etc.). The cultural deficit because of in-vitro contamination can disable certain in-vitro plant techniques especially in India.

\section{In Vitro Contaminations}

The elimination of cultured contaminants of test tube plant breeding ententes in tropical zone like stock plants were found from the full-grown ortet was a very common challenge. Normally these contaminants are very hard in the effect for instances where mass multiplication and propagation of useful plants have failed. The important factor for the successful mass multiplication of in-vitro plant culture asepsis was always played a vital role. The various types 
of cultured dish contaminants are bacteria, virus, fungi or any other microbes. Amidst the particular fungi have been the most conspicuous with common pathogens causing contaminations in laboratory plant culture techniques. The paper presents a straight outline for some fungicides and antibiotics and fungicides (like sterilants and / or disinfectants) and the procedures adopted for elimination of fungal contamination for in-vitro culture such as the development of fungi can disable the entire plant cultivation technique. This paper also highlights some common disinfectant and surface sterilants most frequently used in laboratories for reduction or destruction of fungal contaminants.

\section{In Vitro Culture Pathogens}

Due to the vast development of characteristics of several pathogens (like microbial contaminants) may be a important threat to in-vitro cultures [5]. There were many fungal contaminations that may visible at the primary stage for in-vitro plant culture except cryptic contaminants. Often to out complete contaminations in the nutrient media overgrown plant cultures are taken for consideration [1]. Basically the survival and growth culture are often interfered with in-vitro contaminants for the freedom of pathogens which may be the endmost object for so many laboratory arrangements.

\section{Fungal Contaminations}

The major threat of each and every part of the test tube plant culture techniques are fungal contaminants. These were indicated for the availability of hyphae (threadlike) which appears on the culture media and explants. In fungal mycelia are normally covered with the time and plant culture for colonization of fungi progress. The fungal contaminants unlike other contaminants were visible in the culture media. Similarly in the progress of plant cultures were slower than the growth and development of fungal contaminants. On the other hand the development of fungi in plant culture subjected to the cultured media for the colonized fungi. These colonizing of fungi should be endophytic, cryptic or endogenous. Generally, the fungal contaminations were happened by the Penicilliumcrysogenum, Fusarium, Aspergillusniger, Alternariaspp, Aspergillusoryzae, Cladosporium, Penicillium spp.
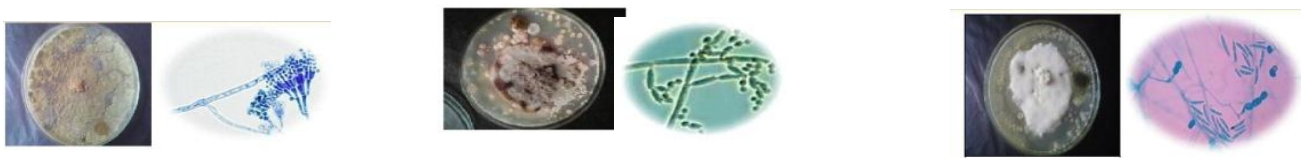

Figure 1:-(a) Penicilliumcrysogenum(b) Fusarium(c) Aspergillusniger
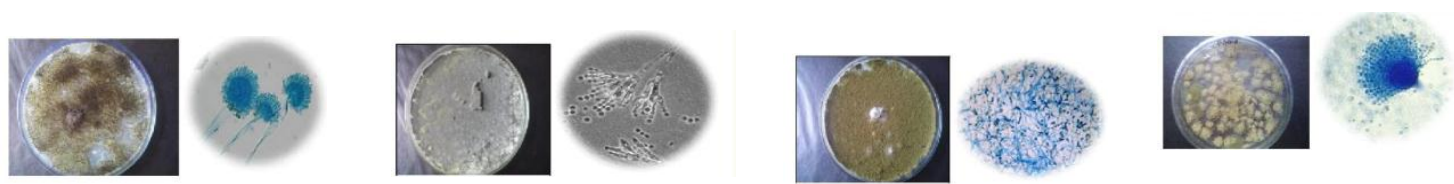

(d) Alternariaspp(e) Penicilliumspp(f) Cladosporium(g) Aspergillusoryzae

\section{Exogenous Fungal Contaminations}

In order to reduce exogenous fungal pathogens in stock plants many fungicides are used. This happens due to such pathogens were available on the exterior part of stock plants or they had sufficient relation between the pathogens and the fungicides and even the spores. On the other hand the inadequate surface disinfection might not remove the spores and exogenous pathogens from the stock of the plants and still there may be a threat for the protocols of plant culture in form of endogenous contaminants. This may be a very hard task to find out the availability if either endogenous, exogenous or both on the stock plants. So this may be a precaution for using proper fungicides (like Benomyl) instead of some other germicides like sodium hypochlorite. Rather than re-disinfecting the explants at sub culturing stage is a fine step to make all most all viable precautions of cultured contaminants dealt with primary stage of decontamination. Re-decontamination may weaken the explants because of cell injury, which may leads to death of plants.

\section{Endogenous Fungal Contamination}

The most benefited microbes are the symbiotic scontamination in the cultured media [6]. The endophytic or endogenous fungi become infectious agent for the plant used in laboratory, when those are sterile, for example, 
those are used under some unfavorable conditions or when the cell walls are weakened [7]. Like this in coalition with cryptic microbes (fungi) or endogenous in the wild environment some plants may live and survive in tropics area [7]. The production of aflatoxin and oxalate caused by fungi like Aspergillusflavus and Aspergillusniger may cause degradation to plant cultures [8]. In order to control the fungal contamination issues the commercial fungicides are used.

\section{Antibiotics}

As antibiotics may play an important role for a hygienic environment in in-vitro cultures. Now a days, the access of fungicides should open a path for proliferation of other contaminants of in-vitro like some microbes, bacteria, protozoa and yeast. So in order to control in-vitro contaminants the broad spectrum antibiotics are in use. The surface sterilants and other disinfectants were not counted as fungicides but wide-range antibiotics are often used.

\section{Experimental Details}

This paper presents the important roles of fungicides that are used in in-vitro for executing the hygienic roles for plant cultures. The above mentioned procedure is called as the vital one in the successful in-vitro plant culture protocols. However, it was very important to select the appropriate disinfectant or fungicides. As the use of a proper, systematic and powerful fungicides required by endophytes for disinfecting the stock plants. This paper also presents the control of in vitro fungal contamination for reducing the loss of cultured plants. For successful outcomes the research work should be carried out in some specified procedures. It was found that during investigation period almost 15 fungal colonies were isolated from 15 numbers of contaminated tubes in PDA plates. The maximum fungal counts were observed in Tube 1 . The maximum fungal colony counts ( 7 colonies) were observed in Tube 1 and minimum count in Tube 4, Tube 5, Tube 6 and Tube 7. Tube 2 and Tube 3 had 2 fungal colonies each.

Table1:-Fungal Counts InPda

\begin{tabular}{|l|l|}
\hline Contaminated Tube Samples & Fungal colonies for $10^{-5}$ dilution CFU/100 ml \\
\hline Tube-1 & $5.40 \times 10^{2}$ \\
\hline Tube-2 & $1.50 \times 10^{2}$ \\
\hline Tube-3 & $2.00 \times 10^{2}$ \\
\hline Tube-4 & $5.30 \times 10^{2}$ \\
\hline Tube-5 & $3.30 \times 10^{2}$ \\
\hline Tube-6 & $1.90 \times 10^{2}$ \\
\hline Tube-7 & $2.40 \times 10^{2}$ \\
\hline
\end{tabular}

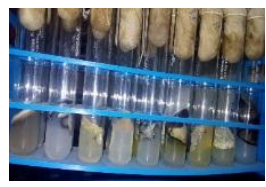

Figure 2:-Contaminated samples

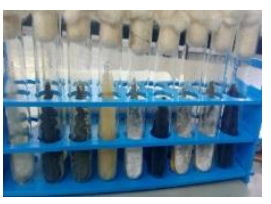

Figure 3:-Purified stock culture 
Table2:-Effect Of Fungicide For Different Fungal Species

\begin{tabular}{|c|c|c|c|}
\hline \multirow[t]{2}{*}{ Types of Fungi } & \multicolumn{3}{|c|}{$\begin{array}{l}\text { Fungicides showing Inhibition Zone } \\
\text { ( in } \mathrm{mm} \text { ) }\end{array}$} \\
\hline & Mancozeb & Carbendazim & Benomyl \\
\hline Penicilliumcrysogenum & 5 & 10 & 5 \\
\hline Fusarium & 10 & 15 & 7 \\
\hline Aspergillusniger & 20 & 10 & Nil \\
\hline Alternariaspp & 35 & 2 & 7 \\
\hline Aspergillusoryzae & 40 & 5 & 4 \\
\hline Cladosporium & 25 & 15 & 10 \\
\hline
\end{tabular}

The effect of fungicides on the isolated fungi were captured which were shown below.
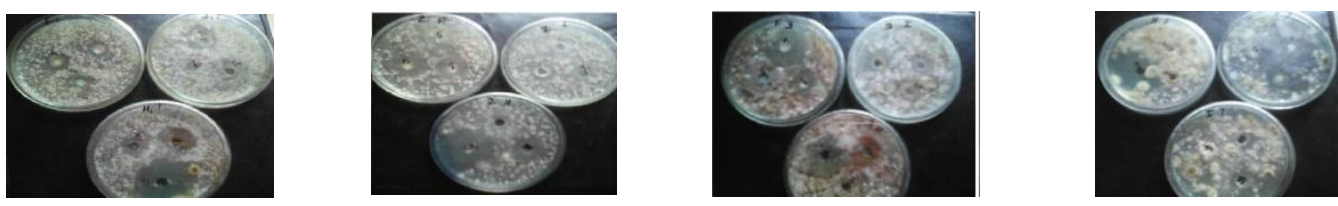

Figure 2:-(a)Penicilliumcrysogenum (b) Fusarium(c) Aspergillusniger(d) Alternariaspp
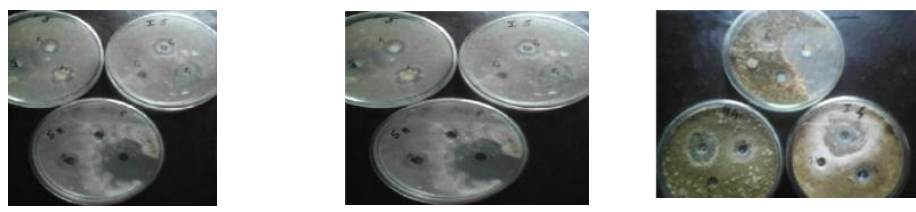

(e) Aspergillusoryzae(f) Cladosporium(g) Penicilliumspp

The below figure indicates affected anthurium plant and status of the plant after fungicidal control.

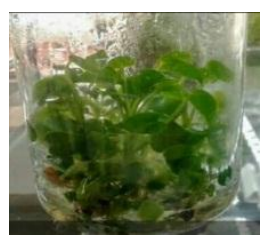

Figure 3:-(a) Anthurium in cultured bottle

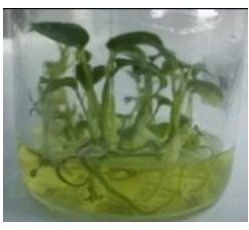

(b) Anthurium plant after fungal control

\section{Conclusions:-}

By using fungicides the elimination of exogenous fungal contaminations were very simple. In this paper a preliminary idea about the control of fungal contamination to reduce the percentage loss of production. The maximum inhibition zone was found in fungus like Aspergillusoryzae (40) followed by 35 against Alternaria and 20 against Aspergillusniger at a dose of $1 \mathrm{mg} / \mathrm{ml}$ in case of Mancozeb fungicide treatment. By using a high dose of fungicides and disinfectants might reduce the cell wall and cell membrane of the plants. Due to the controlling feature of fungus by using fungicides in tissue culture there may be a future study to know the effect of fungicides towards the tissue cultured plant products.

\section{References:-}

1. Pierik, R.L.M. (1987). In Vitro Culture of Higher Plants. Dordecht, Netherlands, p 344 Phytotechnology Laboratories. Antibiotic preparation and storage. www.phytotechlab.com. Cited on 9th August 2011. 
2. George, E.F. (1993). Plant Propagation by Tissue Culture, Part 1. The Technology, Second Edition. Exergetics Ltd. Edington, Wilts, England.

3. Singh, A.K. \& Chand, S, (2003). Somatic embryogenesis and plantlet regeneration from cotyledon explants of a timberyielding leguminous tree DalbergiasissooRoxb. J. Plant Physiology, 160: 415 - 421.

4. Sarasan, V., Kite, G.C., Sileshi, G.W., Stevenson, P.C. (2011) Applications of phytochemical and in vitro techniques for reducing over-harvesting of medicinal and pesticidal plants and generating income for the rural poor. Plant Cell Reports 30: $1163-1172$.

5. Enjalric, F.; Carron, M.P. \&Lardet, L. (1998). Contamination of Primary cultures in tropical areas. The case of Heveabrasiliensis. ActaHorticulturae, 223: 57-65.

6. Herman, E.B. (1990). Non-axenic plant tissue culture: possibility and opportunities. ActaHorticulturae , $280: 233-248$.

7. Darworth, C.E. \& Callan, B.E. (1996). Manipulation of endophytic fungi to promote their utility as vegetation biocontrol agents. In: Endophytic Fungi in Grasses and Woody Fungicides for Plant and Animal Diseases 254 Plants, Systematics, Ecology and Evolution. S.C. Redlin\&L.M.Carris (Eds), pp 209-216.

8. Obuckwe CO, Osagie II (1989) Morphological changes in infected wilt-resistance and wilt susceptible oil palm progenies and hydrolytic enzyme activities associated with Fusariumoxysporum pathogens. Oeagureux. 44(11):8-9.

9. Altan F., Bürün B., Şahin N.( 2010) Fungal contaminants observed during micropropagationofLiliumcandidum L. and the effect of chemotherapeutic substances applied after sterilization.African Journal of Biotechnology 9 (7): 991-995.

10. Cassells, AC. (1991). Problems in Tissue Culture: Culture Contamination. In: Micropropagation:Technology and Application, P.C. Derbergh\& R.H. Zimmerman (Eds), 31- 44, Kluwer,Dordrecht.

11. Dane F. andDalgic Ö.(2005) The Effects of fungicide benomyl (benlate) on growth and mitosisin onion (allium cepa 1.) Root apical meristem. Department of Biology, Science and LiteratureFaculty, Trakya University, 22030, Edirne, Turkey Department of Science Education, Trakya University, 22100, Edirne, Turkey. ActaBiologicaHungarica 56 (1-2):119-128.

12. Danso, K.E., Azu, E., Elegba, W., Asumeng, A., Amoatey, H.M. \&Klu, G.Y.P. (2011).Effective decontamination and subsequentplantlet regeneration of sugarcane (SacchrumofficinarumL.) in vitro. International Journal of Integrative Biology, 11 (2): $90-96$.

13. Déo N., (2013). The effect of fungicide "carbendazim" on in vitro mycelial growth of twophytopathogenic fungi: Case study of Fusariumoxysporumf.sp. lycopersici "strain F20" andColletotrichumcapsici "strain C226.3".Department of Management andDevelopmentStudies,East African Journal of Science and Technology, 2(2):76-96.

14. Geromini K.V.N., Roratto F.B., Ferreira F.G., Camilotti J., Vidigal T.M.A., Valle J.S., ColautoN.B., Linde G.A. (2015) Fungicidal effect of lippia alba essential oil on a white-rot fungus.Maderas.Ciencia y tecnología 17(1): 29 - 38.

15. Helaly M. N., Metwally M. A. E. , Hoseiny H. E., Omar S. A., Sheery N. I. E.(2014) Effect ofnanoparticles on biological contamination of in vitro cultures and organogenic regeneration ofbanana. AJCS 8(4):612-624.

16. Helander, M.L.; Neuvonen, S. \&Ranta, H. (1996). Natural variation and effects ofanthropogenic environmental changes on endophytic fungi in trees. In: S.C. Redlin\& L.M Carris(Eds) Endophytic Fungi in Grasses and Woody Plants. Systematics, Ecology and Evolution pp197- 207.

17. Leifert, C. (1990). Contaminants of plant tissue cultures, Ph.D. Thesis, Nottingham University,School of Agriculture.

18. Maliro, M. (1997). Propagation of Uapacakirkianausing tissue culture techniques. MSc. Thesis, Bunda College of Agriculture, Lilongwe, Malawi, $98 \mathrm{pp}$.

19. Msogoya T, Kayagha H, Mutigitu J, Kulebelwa M, Mamiro M (2012) Identification andmanagement of microbial contaminants of banana in vitro cultures. J Appl Biol. 55: 3987-3994.

20. Mwamba, C.K. (1995). Effect of root - inhabiting fungi on root growth potential of UapacakirkianaMuell Arg. seedlings. Applied Soil Ecology, $2: 217-226$.

21. Pedersen J. C. (1992). Natamycin as a Fungicide in Agar Media. Applied and environmentalmicrobiology, 58 (3) : $1064-$ 1066.

22. Stutzenberger, F. J. and Parle, J. N. (1973). Effect of 2-Substituted Benzimidazoles on theFungusPithomyceschartarum. Journal of General Microbiology, 76:197-209. 